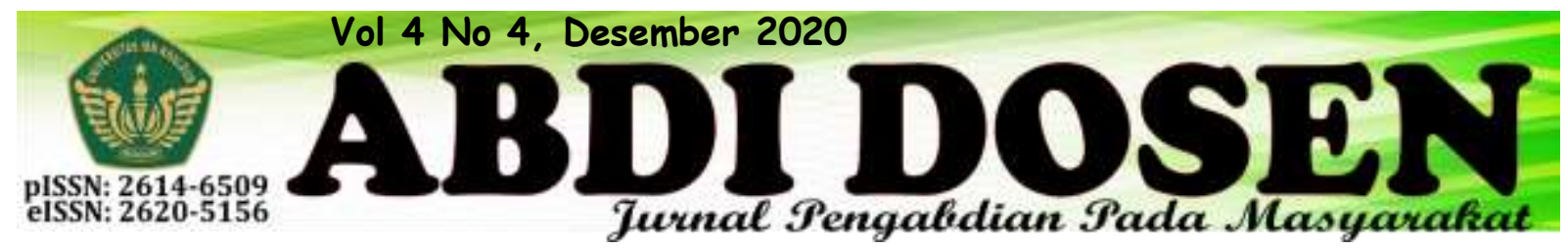

\title{
POTRET PENGABDIAN KEMITRAAN WILAYAH TERPENCIL DI DESA TRANS AGUNG KABUPATEN SELUMA DALAM MENGATASI MASALAH PENDIDIKAN DAERAH TERTINGGAL
}

\author{
Salati Asmahasanah ${ }^{1}$, Eska Perdana Prasetya ${ }^{2}$, Mecky Rendra $^{3}$ \\ salati@fai.uika-bogor.ac.id ${ }^{1}$ \\ eska@uika-bogor.ac.id ${ }^{2}$ \\ Universitas Ibn Khaldun Bogor ${ }^{12}$, Perisai Seluma Bengkulu ${ }^{3}$
}

\begin{abstract}
Abstrak
Kabupaten Seluma Provinsi Bengkulu tergolong ke dalam daftar Lokasi Pusat Kawasan Strategis Nasional (PKSN). Berdasarkan surat sosialisasi penelitian dan pengabdian yang di keluarkan oleh Dikti terdapat Lampiran I Surat No 2276/E3/LL/201 tentang daftar lokasi prioritas kegiatan pengabdian. Permasalahan pertama, Seluma merupakan daerah terpencil, terdapat SD tertinggal dengan kondisi memprihatinkan, pembangunan infrastruktur yang belum merata dengan keadaan akses jalan dan bangunan yang belum layak. Masalah Kedua, sebagian besar anak di desa terpencil putus sekolah hanya sebatas SD dan SMP, hanya beberapa orang saja yang melanjut ke SMA. Anak-anak remaja di Desa sebagian besar lebih memilih membantu orang tua bekerja di perkebunan atau pertanian, bahkan ada yang menikah diusia muda. Metode pengabdian ini terdiri dari, analisa situasi masyarakat, indentifikasi masalah, menentukan tujuan kerja secara speifik, rencana pemecahan masalah, pendekatan sosial melalui pembangunan masyarakat (community development), pelaksanaan kegiatan serta evaluasi kegiatan dan hasil. Tujuan Program Kemitraan Wilayah (PKW) yang telah dilakukan meliputi, (1) terciptanya kemandirian, kenyamanan, dan kesejateraan melalui program pembinaan sekolah dasar terpencil menjadi sekolah yang berkualitas dan layak huni berbasis potensi lokal melalui sinergi antara Perguruan Tinggi, PEMDA dan Organisasi Pemuda dan sosial di Seluma. (2) ditemukan solusi dalam memecahkan permasalahan putus sekolah melalui program penyuluhan "Ayo Sekolah" dan "semangat Lidership" (3) Tersedia bantuan pendidikan bagi siswa yang membutuhkan. (4) angka putus sekolah menurun. (5) Kesadaran masyarakat akan pentingnya sekolah mengalami peningkatan. (6) terwujudnya sekolah yang berkualitas dengan fasilitas yang layak. Tim Pengabdian UIKA Bogor juga bekerjasama melibatkan organisasi pemuda PERISAI dan Ikatan alumni PGSD UNIB menggalang bantuan sosial dan telah diserahkan bantuan berupa paket alat sekolah kepada siswa berupa tas sekolah, buku, alat tulis dan Dispenser beserta galon air minum.
\end{abstract}

\section{Kata kunci: PKW, Seluma, Pendidikan, Daerah Tertinggal}

\section{PENDAHULUAN}

Kabupaten Seluma merupakan salah satu kabupaten hasil pemekaran dari Kabupaten Bengkulu Selatan terletak diwilayah Propinsi Bengkulu, dibentuk berdasarkan Undang-Undang No.3 Tahun 2003 tentang Pembentukan Kabupaten Muko-Muko, Kabupaten Seluma dan Kabupaten Kaur di Propinsi Bengkulu. 
Berdasarkan surat sosialisasi
penelitian dan pengabdian yang di keluarkan oleh Dikti terdapat Lampiran I Surat No 2276/E3/LL/201 tentang daftar lokasi prioritas kegiatan pengabdian. Kabupaten Seluma Provinsi Bengkulu tergolong ke dalam daftar Lokasi Pusat Kawasan Strategis Nasional (PKSN), Hal ini karena di Seluma masih banyak terdapat desa terpencil yang masih tertinggal dan terisolir. Kabupaten Seluma masih sering disematkan sebagai daerah miskin dan tertinggal karena tingkat kesejahteraan yang rendah dan belum meratanya pembangunan infrastruktur. Selain itu terdapat kesenjangan sosial antara si kaya dan miskin,, dengan kondisi daerah yang sebagaian besar masih hutan dan akses jalan yang belum layak. Padahal dari segi potensi sumber daya alam Seluma merupakan salah satu tergolong dearah penghasil sawit dan karet terbesar di Bengkulu. Berikut ini gambaran wilayah Seluma,

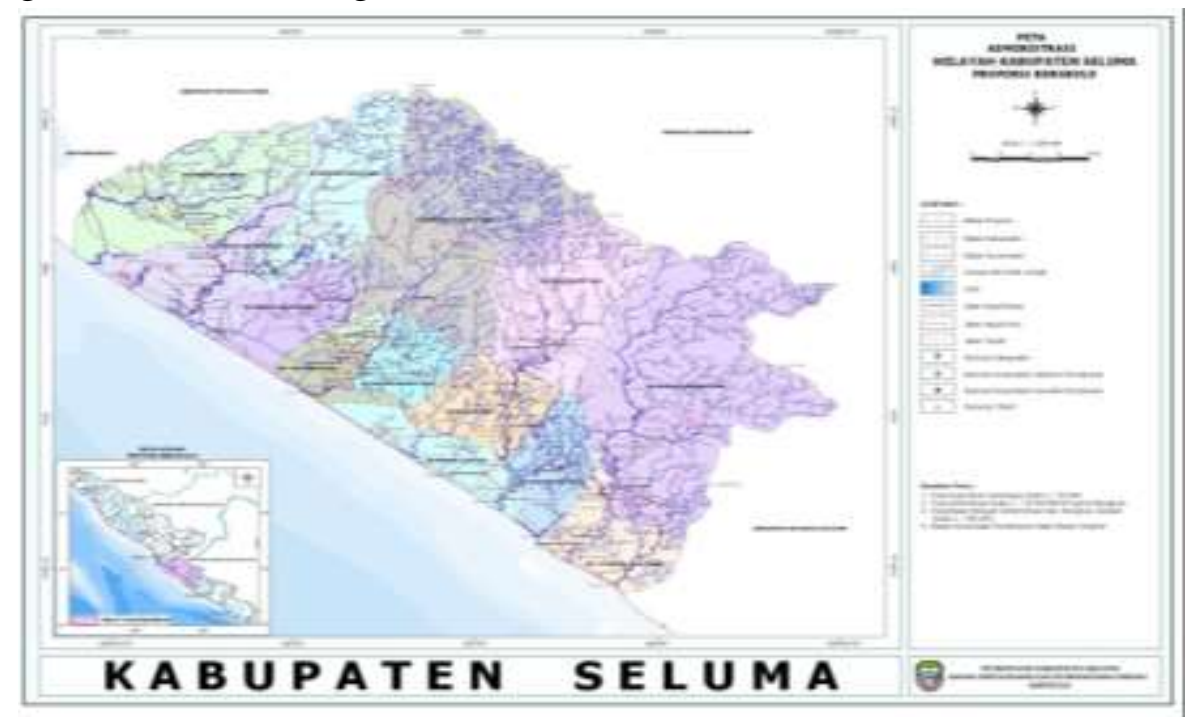

Kabupaten Seluma secara geografis terletak di pantai Barat Sumatera bagian Selatan pada koordinat garis lintang dan bujur yaitu 03.49 ' $55^{\prime} 66^{\prime}$ " LS 04.21' "40'22" LS dan 101.17'27'67" BT 102. 59'40'54" BT dengan luas wilayah 240.004 Ha, Kabupaten Seluma merupakan Kabupaten dengan luas wilayah terbesar ketiga di Propinsi Bengkulu Wilayah Kabupaten Seluma berbatasan langsung dengan Kota Bengkulu, Kabupaten Bengkulu Utara, Kabupaten Bengkulu Selatan, Kabupaten Lahat Propinsi Sumatera Selatan dan Samudra Hindia.

Wilayah Administrasi Kabupaten Seluma dibagi dalam 14 Kecamatan, 182 Desadan 20 Kelurahan dengan jumlah penduduk pada tahun 2017 sebanyak
183.420 jiwa.Masyarakat Kabupaten Seluma sangat majemuk terdiri dari berbagai macam suku, disamping suku asli Serawai yang mayoritas terdapat juga suku Jawa, Bali, Bugis, Batak dan Padang yang hidup berdampingan, membaur dengan penduduk asli secara rukun dan damai. Adapun visi dan misi Seluma adalah sebagai berikut,

\section{Visi}

Visi dari Kabupaten Seluma yaitu "Terwujudnya Masyarakat Kabupaten Seluma Yang Beriman, Unggul Dan Sejahtera Serta Terlaksananya Percepatan Pembangunan Desa Yang Berkeadilan".

\section{Misi}


Berdasarkan hal-hal tersebut diatas, maka misi pembangunan Kabupaten Seluma adalah :

1. Meningkatkan keimanan dan ketaqwaan serta kerukunan umat beragama;

2. Menciptakan budaya yang menerapkan nilai-nilai agama sebagai landasan moral dan etika dalam kehidupan bermasyarakat dan pemerintahan dalam pembangunan daerah serta meningkatkan pengetahuan, pemahaman, dan pengamalan agama;

3. Meningkatkan kualitas pelayanan publik, system kelembagaan dan memperkuat tata kelola pemerintahan yang baik dan bersih, efisien, efektif, professional, transparan, dan akuntabel yang di dukung dengan sistem pengawasan yang efektif guna menekan perilaku korupsi dan kolusi;

4. Mengembangkan kualitas sumber daya manusia melalui peningkatan kualitas dan aksesbilitas masyarakat dalam memperoleh pendidikan dan pelayanan kesehatan penduduk miskin, berkualitas dan terjangkau;

5. Mendorong serta memfasilitasi tumbuh kembangnya kelembagaan masyarakat pada semua aspek kehidupan dengan memberikan perhatian utama kepada pembangunan perekonomian daerah yang memacu pertumbuhan kesempatan berusaha dan kesempatan kerja;
6. Mengembangkan dan memperkuat pertumbuhan ekonomi kerakyatan yang bertumbu pada pengembangan potensi local unggulan melalui sinergi sektor-sektor industri, pertanian, pariwisata, dan sektor lainnya, dengan penekanan pada peningkatan pendapatan masyarakat dan penciptaan lapangan kerja serta berwawasan lingkungan;

7. Percepatan pembangunan dengan melakukan pemberdayaan desa sebagai ujung tombak penyelenggaraan pembangunan yang partisipatif dan demokratif sesuai kebutuhan yang didasarkan pada karakteristik dan potensi sumber daya alam dan sumber daya manusia yang tersedia;

8. Peningkatan kesejahteraan dan perlindungan sosial masyarakat dengan melakukan pemerataan pembangunan secara berkelanjutan untuk mengurangi kesenjangan ekonomi;

9. Meningkatkan pembangunan sarana dan prasarana terutama infrastruktur dasar dalam upaya menunjang pertumbuhan ekonomi daerah dan kesejahteraan masyarakat;

Maka dari itu dapat disimpulkan bahwa visi dan misi Kabupaten Seluma memfokuskan pada pembangunan daerah agar lebiH sejahtera, namun pada kenyataannya sampai 2018 saat ini masih belum maksimal hal ini terlihat jelas banyaknya permasalahan yang terjadi di daerah terpencil. Dari hasil studi pendahuluan yang telah dilakukan oleh tim pengusul dan mitra yang berasal dari Bengkulu namun mengkaji lebih dalam 
permasalahan yang terjadi. Dengan cara melakukan studi pustaka dari berbagai media berita dan melakukan observasi serta wawancara kepada guru daerah terpencil yang dikenal dengan sebutan Guru Garis Depan (GGD) Bengkulu yang ditempatkan di Kabupaten Seluma. Diperoleh informasi memang benar bahwa Seluma memiliki permasalahan penting yang pertama, Seluma merupakan daerah terpencil, terdapat SD tertinggal dengan kondisi memprihatinkan, pembangunan infrastruktur yang belum merata dengan keadaan akses jalan dan bangunan yang belum layak. Masalah Kedua, sebagian besar anak di desa terpencil putus sekolah hanya sebatas SD dan SMP, hanya beberapa orang saja yang melanjut ke SMA. Anak-anak remaja di Desa sebagian besar lebih memilih membantu orang tua bekerja di perkebunan atau pertanian, bahkan ada yang menikah diusia muda.

Sehubungan dengan permasalahan ini, seperti yang di kutip pada berita kupasbengkulu.com (2016), Sekretaris Bappeda Seluma, Marah Halim, menjelaskan bahwa daerah terpencil yang

\section{METODE PENGABDIAN}

Metode ialah pola atau sistim tindakan yang akan dilakukan, ataupun urutan atau tahapan-tahapan yang perlu dalam menjalankan kegiatan pengabdian pada masyarakat. Adapun tahapan yang dilaksanakan pada PKW ini adalah:

\section{Analisa situasi masyarakat.}

Kegiatan pengabdian pada masyarkat harus dimulai dari niat untuk membantu masyarakat. Tahap ini dapat dilakukan dengan dua sub tahapan, yang terbagi lagi menjadi beberapa kemungkinan. Pertama : menentukan khalayak sasaran,apakah : a. Masyarakat luas disematkan pada Kabupaten Seluma pihak pemerintah sudah berusaha untuk mengatasinya namun memang bertahap dan belum maksimal. Fokus Rencana Pembangunan Jangka Menengah Daerah (RPJMD) Kabupaten Seluma dari 2016 sampai 2019 yaitu lima tahun ke depan sudah dipersiapkan. Di tahun pertama akan difokuskan pada pembangunan infrastruktur. Kemudian di tahun ke dua akan beralih pada sektor unggulan pertanian, peternakan, perkebunan, dan perikanan. Pada tahun ke tiga, urusan pendidikan dan kesehatan menjadi fokus utama. Sementara di tahun ke empat, akan lebih gencar dalam upaya pengentasan kemiskinan, dan di tahun ke lima akan mengutamakan masalah keagamaan dan sosial. Harapannya tahun 2019 Seluma sudah tidak masuk lagi dalam daftar daerah tertinggal, maka sebenarnya fokus utama pemerintah daerah Seluma adalah pengentasan daerah tertinggal. Dan pendidikan dasar menjadi salahsatu potret yang kondisi salahsatu sekolah yang terdapat di SDN 178 Desa Trans Agung yang sangat memperihatinkan. secara keseluruhan ; b. Komunitas tertentu; c. Khalayak atau organisasi tertentu; d. Orang-orang tertentu dalam masyarakat. Lokasi sasaran yang ditentukan adalah fokus di Desa Trans Agung Kecamatan Ulu Talo Kabupaten Seluma.

\section{Indentifikasi masalah}

Hasil dari kerja analisis yang mencakup sasaran dan bidang permasalahan semakin konkrit perumusan masalahnya, semakin baiklah hasil yang akan dicapai dalam perencanaan ini. 
Permasalahan pertama, Seluma merupakan daerah terpencil, terdapat SD tertinggal dengan kondisi memprihatinkan, pembangunan infrastruktur yang belum merata dengan keadaan akses jalan dan bangunan yang belum layak. Masalah Kedua, sebagian besar anak di desa terpencil putus sekolah hanya sebatas SD dan SMP, hanya beberapa orang saja yang melanjut ke SMA. Anak-anak remaja di Desa sebagian besar lebih memilih membantu orang tua bekerja di perkebunan atau pertanian, bahkan ada yang menikah diusia muda.

\section{Menentukan tujuan kerja secara speifik}

Pada tahap ini harus dapat ditentukan "kondisi baru" mana yang ingin dihasilkan melalui kegiatan pengabdian nantinya. Dengan kata lain perubahan apa yang diinginkan. Seandanya perubahan itu dapat dikuantifikasikan akan membuat tujuan kerja itu lebih jelas, kalaupun tidak ukuran kuantitatipun dapat diterima. Yang penting dapat dibedakan antara kondisi sekarang dan kondisi baru yang ingin dicapai dengan kegiatan pengabdian itu. Tujuan PKW adalah (1) Terciptanya kemandirian, kenyamanan, dan kesejateraan melalui program pembinaan sekolah dasar terpencil menjadi sekolah yang berkualitas dan layak huni berbasis potensi lokal melalui sinergi antara Perguruan Tinggi, PEMDA dan Organisasi Pemuda dan sosial di Seluma. (2) Ditemukan solusi dalam memecahkan permasalahan putus sekolah melalui program penyuluhan "Ayo Sekolah" dan "semangat Lidership" (3) Tersedia bantuan pendidikan bagi siswa yang membutuhkan. (4) Angka putus sekolah menurun. (5) Kesadaran masyarakat akan pentingnya sekolah mengalami peningkatan. (6) Terwujudnya sekolah yang berkualitas dengan fasilitas yang layak.

\section{Rencana pemecahan masalah}

Masalah yang sudah diidentifikasi perlu dipecahkan dan sekaligus mencapai tujuan (kondisi baru) yang telah ditetapkan. Semuanya itu perlu direncanakan dalam tahap ini, yang terdiri dari sub-tahapan, yaitu : a. Mencari alternatif pemecahan masalah ; b. Memilih salah satu alternatief yang terbaik. Solusi yang dirancang dalam memecahkan masalah ini adalah fokus mengatasi sekolah tertinggal dan melaksanakan kegaiatan untuk meminimalisir anak putus sekolah yang perencanaannya melibatkan mitra dan warga setempat. Menyelenggarakan pelatihan dan workshop kurikulum dan manajemen sekolah berbasis masyarakat. Menghadirkan pakar pendidikan dasar dari PGMI UIKA dan PGSD UNIB untuk memberikan pembinaan menuju sekolah yang berkualitas. Melakukan kerjasama dengan organisasi PERISAI dan mahasiswa untuk mengadakan Training Motivasi dan Games "Pentingnya Pendidikan" dan "Semangat Lidership" untuk anak- 
anak dan pemuda Desa Trans Agung dan sekitarnya. Bekerjasama dengan Pemda dan Diknas Kabupaten Seluma untuk menyediakan bantuan biaya pendidikan gratis dan dana pengembangan sekolah. Melibatkan organisasi pemuda dan ikagtan alumni kampus setempat dan lembaga sosial untuk menggalang dana bantuan perlengkapan sekolah.

\section{Pendekatan sosial}

Yang dimaksud adalah pendekatan terhadap masyarakat sasaran. PKW melaksanakan program pemberdayaan melalui pendekatan pembangunan masyarakat (Community development), tim melibatkan masyarakat dan menggali potensi lokal dalam pelaksanaan kegiatan pengabdian. Prinsipnya ialah bahwa masyarakat sasaran harus dijadikan subyek dan bukan obyek dari kegiatan pengabdian pada masyarakat ini. Untuk ini masyarakat desa Trans Agung harus sebanyak mungkin dan sejauh mungkin dilibatkan dalam kegiatan, termasuk dalam proses perencanaan. Kalau dalam proses perencanaan mungkin hanya beberapa orang saja yang dilibatkan, maka pada tahap pendekatan sosial ini sebaiknya semua orang yang akan terkena program kegiatan dijadikan sasaran pendekatan. Mereka harus menyadari bahwa mereka menghadapi masalah seperti yang dirumuskan diatas, mereka harus ditumbuhkan kesadarannya bahwa masalah itu adalah masalah mereka yang perlu untuk dipecahkan mereka.

\section{Pelaksanaan kegiatan}

Meskipun sudah sampai pada tahap pelaksanaan, tetapi tidak berarti perencanaan sudah tidak diperlukan lagi. Justru pada tahap ini pelaksanaan kegiatan yang akan segera dilakukan itu harus direncanakan secara matang dan terinci. Penyusunan rencana kerja ini termasuk :

a.Penetapan bagaimana kegiatan itu akan dilakukan ; b. Penetapan waktu pelaksanaannya ; c. Penetapan tempat-tempat pelaksanaan kegiatan ; d. Penetapan orang-orang yang akan terlibat dalam kegiatan. Untuk penyusunan rencana kerja itu pendapat-pendapat dan saran-saran dari masyarakat sasaran sangat perlu untuk diperhatikan. Sekali lagi perlu diusahakan agar masyarakat beranggapan bahwa kegiatan itu adalah kegiatan mereka, usaha mereka untuk mengatasi masalah-masalah yang mereka hadapi dengan mendapatkan bantuan dari unsur perguruan tinggi, dan mungkin juga dari unsur-unsur lain, misalnya dari berbagai instansi yang relevan, Sebaliknya harus dihindarkan tumbuhnya anggapan masyarakat bahwa kegiataan itu adalah kegiatan perguruan tinggi dan untuk keperluan perguruan tinggi, sehingga mereka hanyalah membantu.

\section{Evaluasi kegiatan dan hasil}

Setiap tahapan memang perlu dievaluasi, sehingga timbul keyakinan bahwa segala yang telah 
diputuskan adalah benar, dan dapat melangkah ketahap berikutnya secara aman. Namun hal itu tidak menghilangkan kemungkinan diadakannya penyempurnaanpenyempurnaan selama proses kegiatan berlangsung. Yang tidak kurang pentingnya adalah evaluasi terhadap hasil ataupun dampak dari seluruh kegiatan pengabdian masyarakat itu terhadap masyarakat sasaran. Proses evaluasi itu dapat mengikutsertakan

unsur

\section{HASIL PEMBAHASAN}

Tim pengabdian UIKA bogor bermitra dengan lembaga sosial di Seluma yang merupakan organisasi pemuda seluma yang tergabung dalam Persatuan Remaja Islam Inovatif (PERISAI). Alasan memilih PERISAI karena snggota organisasi PERISAI berasal dari pemuda aktif setiap kecamatan di Kabupaten Seluma. Dan merupakan salah satu organisasi yang berhasil menjalin kerjasama dengan Pemerintah Daerah (Pemda) Seluma dalam kegiatan peduli pendidikan, kepemudaan dan sosial. Selain itu PERISAI juga bekerjasama dengan lembaga atau organisasi seperti PMI, Ikatan bujang Gadis Seluma, Himasel, ormas dan organisasi sosial, Ikabes PGSD Universitas Bengkulu.

Kerja sama dengan mitra yang berasal dari daerah setempat merupakan potensi lokal daerah yang menjadi dukungan yang sangat penting dan dibutuhkan tim pengusul dalam mewujudkan kegiatan pengabdian. Hal ini agar dapat menangani masalah yang terjadi sehingga program berjalan secara berkelanjutan dan tepat sasaran. Selain itu

masyarakat, sehingga mereka tidak harus mengetahui apa hasil dari kegiatan selama ini, tetapi juga belajar bagaimana mengetahui dan mengukur perubahan-perubahan yang terjadi.. Hasil evaluasi itu tidak hanya penting sebagai kelengkapan administrasif, tetapi juga sangat penting untuk diketahui oleh semua orang yang terlibat yaitu tim pengusul dan mitra, termasuk masyarakat sasaran.

potensi lokal yang dapat digali adalah melibatkan swadaya masyarakat. Pelibatan warga sekitar sangat diperlukan sebagai wujud dukungan guna mewujudkan sekolah dasar berkualitas dan meminimalisir angkat putus sekolah.

Maka dari itu potret pendidikan di daerah tertinggal memang sangat memperihatinkan dan perlu kerjasama dalam menanganinya. Berkaitan dengan masalah pertama, yaitu mengenai desa terpencil salah satunya terdapat di daerah tertinggal desa Trans Agung Kecamatan Ulu Talo Kabupaten Seluma Provinsi Bengkulu terdapat SD Negeri 178 yang tidak terurus dengan baik. Pemerintah setempat menjanjikan akan ada pembangunan dan renovasi tapi hanya sekedar janji dikarenakan terbatasnya anggaran daerah sehingga belum semua sekolah di daerah pedalaman bisa diperhatikan dengan maksimal. Jarak desa dengan kota $40 \mathrm{KM}$ dengan akses jalan yang belum layak membuat SDN ini semakin kurang diperhatikan. Berikut ini gambaran kondisi akses jalan desa dan keadaan sekolah di Desa Trans Agung, 


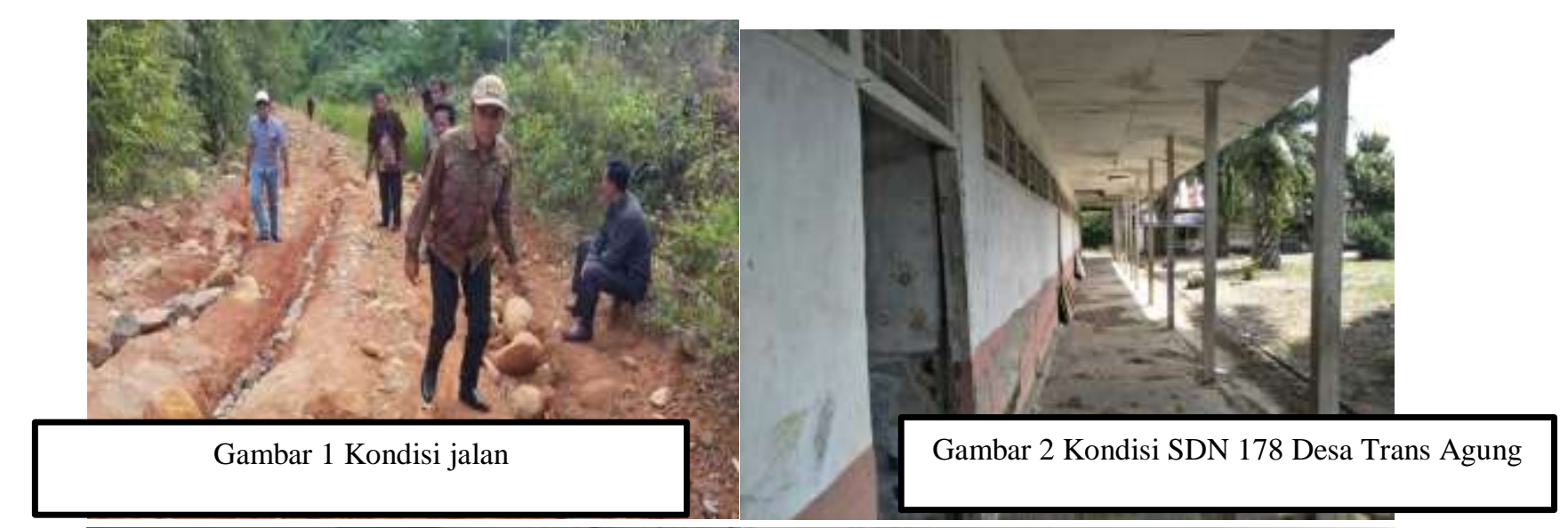

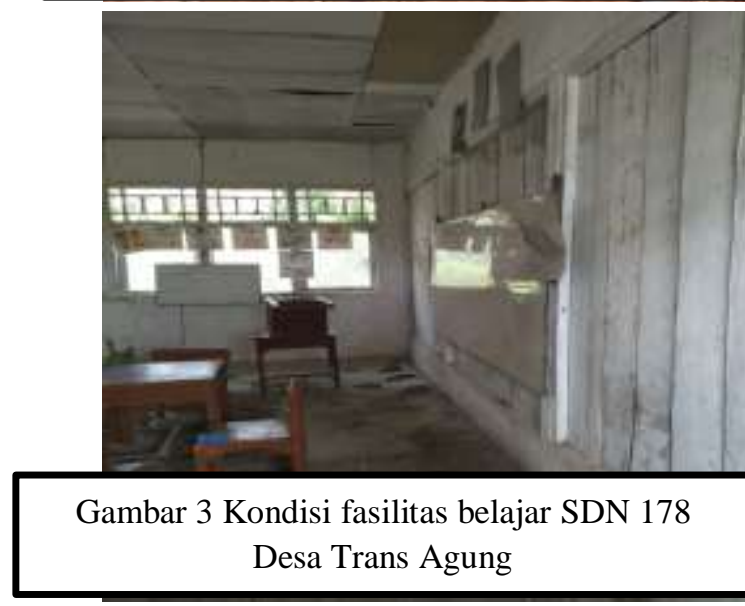

SDN 178 Seluma memiliki Sumber Daya Manusia (SDM) yang masih minim hal ini terlihat dari data sekolah yang hanya memiliki lima guru yang terdiri dari tiga orang PNS dan dua orang guru honorer dan tahun ini yang PNS ada yang akan pension sehingga tenaga pengajar akan berkurang. Sedangkan jumlah siswa hanya sedikit yaitu terdapat 23 siswa yang tersebar dari kelas satu sampai kelas enam. Penyebanya adalah karena orang tua wali murid di sekitaran desa lebih memilih menyekolahkan anaknya ke SD di desa tetangga walau jaraknya jauh, hal ini dikarenakan kondisi SDN 178 yang memprihatinkan.

Sehubungan dengan itu, dari hasil wawancara kepada pihak sekolah maka diperoleh informasi, selain kekurangan SDM guru dan siswa yang minim, dari segi fisik SDN 178 sangat membutuhkan sarana prasarana, bangunan, perpustakaan, WC, media pembelajaran. Sedangkan dari segi

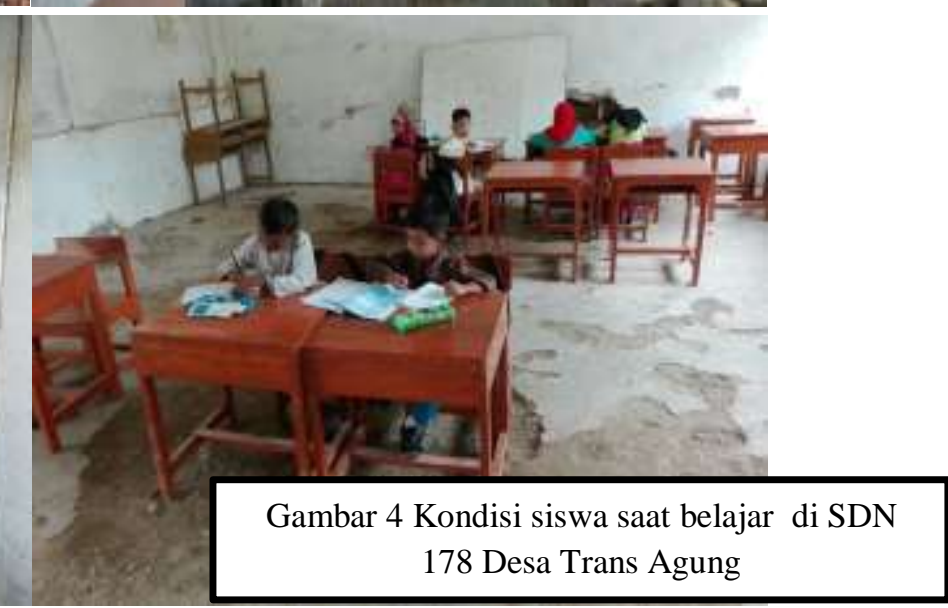

manajemen sekolah mereka sangat membutuhkan pembinaan dan bantuan dalam memperbaiki sistem administrasi sekolah dan pengelolaan sekolah.

Masalah kedua, angka putus sekolah yaitu menunjukkan tingkat putus sekolah di suatu jenjang pendidikan. Menurut Gunawan (2010), putus sekolah merupakan predikat yang diberikan kepada mantan peserta didik yang tidak mampu menyelesaikan suatu jenjang pendidikan, sehingga tidak dapat melanjutkan studinya ke jenjang pendidikan berikutnya. Pada umumnya angka putus sekolah di Bengkulu masih tinggi, sebagian karena kelemahan ekonomi rumah tangga untuk membiayai pendidikan," yang diungkapkan Parial selaku Ketua Komisi IV DPRD Provinsi Bengkulu. mengutip data resmi di situs Kementerian Pendidikan Nasional sejak Januari 2013 yang menyebutkan sebanyak 15.128 orang anak putus sekolah di Kabupaten Seluma 
yang putus sekolah. Dari jumlah itu terdiri atas golongan anak Sekolah Dasar (SD) usia 7-12 tahun tercatat 2.827 orang, anak usia 13-17 tahun atau tingkat SMP sebanyak 5.229 orang dan anak usia 16-18 tahun tercatat 7.126 orang. Di Desa Trans Agung Kabupaten Seluma sebagian besar putus sekolah ke jenjang yang lebih tinggi, rata-rata hanya sebatas SD dan SMP, sebagian kecil yang tamat SMA.

Tingginya angka anak putus sekolah itu penyebabnya antara lain faktor ekonomi dan masih minimnya kesadaran orang tua menyekolahkan anaknya, terutama di desa terpencil. Masalah anak putus sekolah tentu saja bukanlah terjadi tanpa sebab, tetapi ada faktor-faktor yang menyebabkan terjadinya masalah anak putus sekolah. Burhannudin (2008) menyatakan bahwa setidaknya ada enam faktor yang menyebabkan terjadinya putus sekolah khususnya pada jenjang pendidikan dasar yaitu faktor ekonomi, minat untuk bersekolah rendah, perhatian orang tua yang kurang, fasilitas belajar yang kurang mendukung, faktor budaya dan lokasi atau jarak sekolah.

Berkaitan dengan masalah ini dikaitkan dari hasil penelitian sebelumnya oleh Madani (2016) menjelaskan bahwa (1) faktor yang menyebabkan anak petani putus sekolah karena tidak mampu membiayai anaknya, ada juga anak yang memang tidak mau sekolah, kurangnya perhatian orang tua, hal demikian terjadi karena penghasilan yang tidak menentu. (2) Peranan anak dalam membantu ekonomi keluarga dapat dilihat dari keberadaan anak dalam keluarga, peranan anak sangat berpengaruh, sebab tingkat pendapatan keluarga ada perubahan jika dibandingkan dari sebelumnya, karena sebelum anak bekerja pendapatan keluarga sangat minim. Maka dari itu pula anak putus sekolah karena faktor ekonomi rendah dan tidak ada biaya, sehingga anak memutuskan putus sekolah dan punya inisiatif untuk membantu orang tua dan mencari kerja. Dalam hal ini membantu dan menutupi kekurangan ekonomi keluarga menunjukkan kondisi keluarga petani rata-rata serba kekurangan dengan melihat penghasilan yang didapatnya sehingga membutuhkan peran anak.

Pemberdayaan warga melalui pendekatan pembangunan masyarakat (Community development) akan lebih bermakna dalam kegiatan pengabdian, agar tercipta masyarakat yang mandiri dan sejahtera. Berikut ini beberapa program yang dilaksanakan dalam mengatasi masalah sekolah tertinggal yaitu menjadi fasilitator dan bekerjasama dengan mitra dalam mewujudkan penyediaan sarana prasarana, renovasi bangunan, perpustakaan, WC, dan pengadaan media pembelajaran. Dilaksanakan pembinaan dan pendampingan dalam memperbaiki sistem administrasi sekolah dan pengelolaan pembelajaran di sekolah agar pendidikan lebih berkualitas. Agar siswa tidak putus sekolah tim bekerjasama dengan organisasi PERISAI dan mahasiswa untuk mengadakan Training Motivasi dan Games "Ayo Sekolah" dan "Semangat Lidership" untuk anak-anak dan pemuda Desa Trans Agung dan sekitarnya. Tim Pengabdian UIKA Bogor juga bekerjasama melibatkan organisasi pemuda PERISAI dan Ikatan alumni PGSD UNIB menggalang bantuan sosial dan telah diserahkan bantuan berupa paket alat sekolah kepada siswa berupa tas sekolah, buku, alat tulis dan Dispenser beserta galon air minum. 


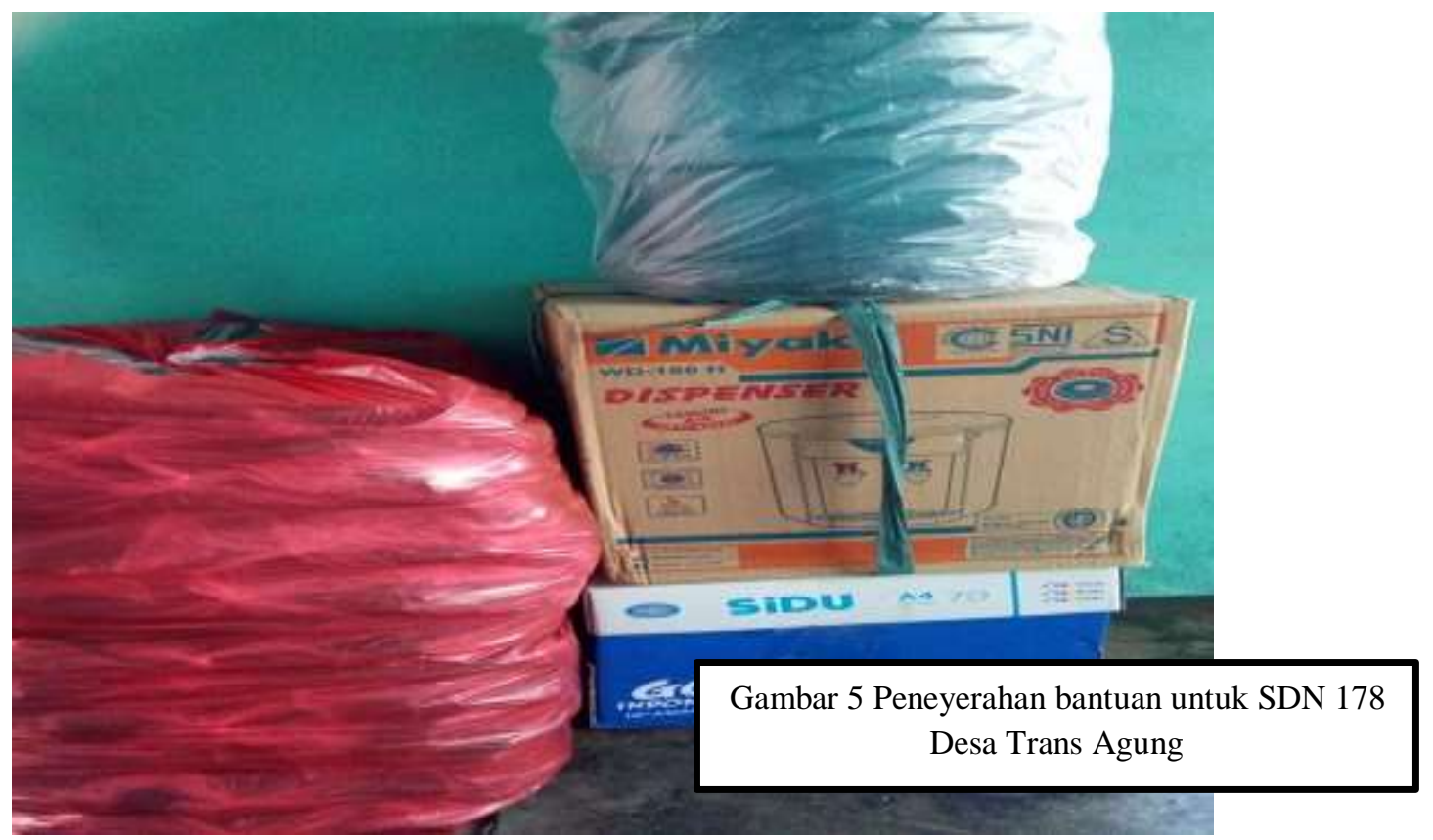

Selain sarana pendidikan maka kualitas sumber daya guru juga harus ditungkatkan. Guru adalah aktor utama dalam pelaksanaan pendidikan yang harus diutamakan dan diperhatikan (Asmahasanah, 2018). Maka kedepannya

\section{SIMPULAN}

Kerja sama dengan mitra yang berasal dari daerah setempat merupakan potensi lokal daerah yang menjadi dukungan yang sangat penting dan dibutuhkan tim pengusul dalam mewujudkan kegiatan pengabdian. Hal ini agar dapat menangani masalah yang terjadi sehingga program berjalan secara berkelanjutan dan tepat sasaran. Selain itu potensi lokal yang dapat digali adalah melibatkan swadaya masyarakat. Pelibatan warga sekitar sangat diperlukan sebagai wujud dukungan guna mewujudkan pendidikan berkualitas dan meminimalisir angkat putus sekolah. Pemberdayaan warga melalui pendekatan pembangunan masyarakat (Community development) akan lebih bermakna dalam kegiatan pengabdian, agar tercipta masyarakat yang program tindak lanjut perlu di realisasikan yaitu pendammpingan dan pembinaan kompetensi guru melalui diklat dan pelatihan manajemen sekolah yang berkualitas.

mandiri dan sejahtera. Metode pengabdian ini terdiri dari, analisa situasi masyarakat, indentifikasi masalah, menentukan tujuan kerja secara speifik, rencana pemecahan masalah, pendekatan sosial melalui pembangunan masyarakat (community development), pelaksanaan kegiatan serta evaluasi kegiatan dan hasil. Agar siswa tidak putus sekolah tim bekerjasama dengan organisasi PERISAI dan mahasiswa untuk mengadakan Training Motivasi dan Games "Ayo Sekolah" dan "Semangat Lidership". Tim Pengabdian UIKA Bogor juga bekerjasama melibatkan organisasi pemuda PERISAI dan Ikatan alumni PGSD UNIB menggalang bantuan sosial dan telah diserahkan bantuan berupa paket alat sekolah kepada siswa berupa tas 
sekolah, buku, alat tulis dan Dispenser beserta galon air minum.

\section{DAFTAR PUSTAKA}

Asmahasanah, S., Sa'diyah, M., \& ibdalsyah, I. (2018). Analisis Keterampilan Mengajar Guru dan Penanaman Nilai Positif Melalui Pemanfaatan Kebun Sekolah. Sekolah Dasar: Kajian Teori dan Praktik Pendidikan, 27(2), 167-173. doi:http://dx.doi.org/10.17977/um00 9v27i22018p167

Gunawan Ary.2010. Sosiologi Pendidikan. Jakarta: Raja Grafindo Persada

Madani dkk. 2016. Perilaku anak putus sekolah. Jurnal Equilibrium Pendidikan Sosiologi Volume IV No.2 November 2016. Issn e-24770221 p-2339-2401

Burhannudin, "Penetaan Anak Tidak dan putus Sekolah di Kota Mataram dan Kabupaten Sumbawa Besar Usia 512

Tahun”, http://www.puslitjaknov.org /data/file/2008/
makalah_peserta/30_Burhanudin_Pe metaan.pdf/ di akses tanggal 1 September 2018.

Website Kabupaten Seluma: http://selumakab.go.id/sejarahseluma/

http://selumakab.go.id/visi-dan-misi/

Media Berita: Ini Fokus RPJMD Seluma Lima Tahun Ke Depan

http://kupasbengkulu.com/ini-fokus-rpjmdseluma-lima-tahun-ke-depan. 28 Juli $\underline{2016}$

https://www.republika.co.id/berita/pendidi kan/eduaction/13/01/28/mhbwauperda-sms-cara-bengkulu-tekanangka-putus-sekolah

Rangga Pramudya https://news.detik.com/opini/859776/ dua-solusi-menolong-anak-putus$\underline{\text { sekolah }}$ 